\title{
PHENOTYPIC VARIABILITY OF MILK TRAITS IN SIMMENTAL BULL DAMS ${ }^{1}$
}

\author{
V. Pantelić, Z. Skalicki, M. M. Petrović, S. Aleksić, B. Miščević, Dušica Ostojić
}

Contents: Production of milk has its own biological and economical meaning. Together with reproduction it represents material basis for survival of the species. In production sense, except the fact that milk is considered to be feedstuff of highest quality in human nutrition, it also provides basis for production of meat through breeding of calves. Milk yield is most important trait in milk production and it is determined for entire lactation as well as standard lactation of 305 days.

Milk traits such as production of milk, of milk fat, 4\% FCM and content of milk fat in standard lactation of 305 days were investigated. Production of milk in standard lactations enables comparison of lactations of different durations. Also, the effect of order of lactation and calving season on mentioned traits was investigated in detail using the method of Least Squares (Harvey 1987).

Order of lactation demonstrated highly significant effect $(\mathrm{P}<0,01)$ on all milk traits contrary to calving season without any significant effect $(\mathrm{P}>0,05)$ on any of the investigated traits.

Mean values of general average for production of milk were $5.630 .27 \mathrm{~kg}$, content of milk fat $3.98 \%$, production of milk fat $225.22 \mathrm{~kg}$. and production of $4 \%$ FCM $5.630 .38 \mathrm{~kg}$.

Key words: bull dams, Simmental breed, milk yield, lactation, season of calving

\section{Introduction and review of literature}

Milk yield of Simmental cattle in our country is considerably lower compared to main breeding regions in Europe (Austria, Switzerland, Germany, and France) even by approx. 1.000 to $1500 \mathrm{~kg}$. Production potential of Simmental cattle in our conditions until now was $5.000 \mathrm{~kg}$ of milk with $4.00 \%$ of milk fat and there are certain possibilities in this regard to reach the level achieved in developed countries of Europe. Increase of production and quality of milk as well as intensity of fertility are main prerequisites of modern cattle production.

Investigating the variability of production and reproduction traits of Simmental cows Lazarevic et al. (1985) have determined the highest quantity of milk in the third (III) lactation $(4.776 \mathrm{~kg})$ and the lowest in the first (I) lactation $(4.337 \mathrm{~kg})$. Statistically significant differences were established between the III and I, II, V and other lactations $(\mathrm{P}<0,05)$.

Petrović M. M. et al. (1997) determined highly significant effect of season of calving on production of milk, milk fat and 4\% FCM compared to general average $(\mathrm{P}<0,01)$. Heifers which had calved in February, March and April produced in lactation by $109,7 \mathrm{~kg}$ more 4\% FCM compared to general average or by 268,4 $\mathrm{kg}$ more compared to heifers that had calved in August, September and October.

Annual report of the Schweizerischer Fleckviehzuchtverband (1998) - Swiss Association of Breeders of Simmental Cattle presented data on milk yield for 233.489 registered cows. Average production of milk was $6.100 \mathrm{~kg}$ with $4,14 \%$ of milk fat. In 447 selected bull dams average milk yield was $7.929 \mathrm{~kg}$ and content of fat in milk $4,15 \%$.

Petrović M. (2000) investigated the longevity, production of milk and milk fat of cows of Simmental breed on farm on mountain Zlatibor. Author established average production of milk in standard lactation of $4.282 \mathrm{~kg}$. The lowest yield was realized in the first lactation $3.111 \mathrm{~kg}$ and the highest in the fifth lactation $4.875 \mathrm{~kg}$. Content of milk fat was 3,67\%. Production of 4\% FCM in standard lactation was $4.065 \mathrm{~kg}$.

In year 2000, Austria had 258.700 registered cows of Simmental breed with milk production of $5.751 \mathrm{~kg}$ of milk with 4,15\% milk fat (Pumberger R., Pichler R., 2001). In 1999, 1.500 bull dams were selected in Austria for production of bulls. These bull dams achieved production of $7.826 \mathrm{~kg}$ of milk with $4,35 \%$ milk fat.

${ }^{1}$ Original scientific paper - Originalni naučni rad Original scientific paper

${ }^{2} \mathrm{Mr}$ Vlada Pantelić, research assistant, Dr Milan M. Petrović, scientific counselor, Dr Stevica Aleksić, scientific counselor, Dr Branislav Miščević, scientific counselor, Grad.eng. Dušica Ostojić, research trainee, Institute for Animal Husbandry, Belgrade-Zemun; Dr Zlatko Skalicki, full professor, Faculty of agriculture, Zemun. 
Trifunović et al. (2002) investigated the effect of certain paragenetic factors on milk traits. Highly significant effect $(\mathrm{P}<0,01)$ of order of lactation on milk yield and yield of milk fat was established as well as on yield of $4 \% \mathrm{FCM}$, but not on the content of milk fat $(\mathrm{P}>0,05)$.

In 2002 new world record was registered for milk yield of Simmental cows. Cow Genja from Austria realized in its third standard lactation milk yield of $18.826 \mathrm{~kg}$ with $4,20 \%$ milk fat content.

\section{Material and methods}

Our research included 292 Simmental cows selected as bull dams on the territory of the Republic of Serbia during 2002. Selection of cows to be included in herd of bull dams was carried out after the first lactation had ended, or in other words selection was based on following lactations.

Investigations included following milk traits in standard lactation:

- Production of milk, kg

- $\quad$ Milk fat content, \%

- $\quad$ Production of milk fat, $\mathrm{kg}$

Production of $4 \%$ FCM, $\mathrm{kg}$

Standardization of lactation to 305 days was carried out using coefficients according to Nenadović, 1974. Correction of milk yield to 4\% FCM was carried out using Gaines-Davidson formula:

where:

$$
4 \% \mathrm{MKM}=0,4 \mathrm{M}+15 \mathrm{~F}
$$

$\mathrm{M}-$ milk yield

$\mathrm{F}$ - yield of milk fat.

Analysis of the effect of paragenetic factors on investigated milk traits was carried out using the method of Least Squares (Harvey 1987) - fixed model:

$$
\mathrm{Y}_{m l k}=\mu+\mathrm{L}_{l+} \mathrm{S}_{k}+\mathrm{e}_{m l k}
$$

where: $\mathrm{Y}_{m l k}=$ demonstration of investigated trait of $m$ cow producing in $l$ lactation, and who calved in $k$ season.

$$
\begin{array}{ll}
\mu & =\text { general average } \\
\mathrm{L}_{l} & =\text { fixed effect of } l \text { lactation } \\
\mathrm{S}_{k} & =\text { fixed effect of } \mathrm{k} \text { calving season } \\
\mathrm{e}_{m l k} & =\text { random error }
\end{array}
$$

\section{Results and discussion}

Table 1. General average, mean values of least squares and their errors and significance of the effect of lactation on milk traits

Tabela 1. Opšti prosek, srednje vrednosti najmanjih kvadrata i njihove greške i značajnost uticaja laktacije na osobine mlečnosti

\begin{tabular}{|c|c|c|c|c|c|c|c|c|}
\hline $\begin{array}{c}\text { Laktacija } \\
\text { Lactation }\end{array}$ & $\begin{array}{c}\text { PM } \\
\text { MP }\end{array}$ & Slsm & $\begin{array}{c}\text { SMM } \\
\text { CMF }\end{array}$ & Slsm & $\begin{array}{c}\text { PMM } \\
\text { MFP }\end{array}$ & Slsm & $\begin{array}{c}\text { 4\%MKM } \\
\text { 4\% FCM }\end{array}$ & Slsm \\
\hline Op. Prosek / Gen. Av. & \multicolumn{2}{|c|}{$5.630 .27 \mathrm{~kg}$} & \multicolumn{2}{|c|}{$3.98 \%$} & \multicolumn{2}{|c|}{$225.22 \mathrm{~kg}$} & \multicolumn{2}{|c|}{$5.630 .38 \mathrm{~kg}$} \\
\hline $\mathbf{1 .}$ & 4767.89 & 146.17 & 3.77 & 0.02 & 179.07 & 6.05 & 4593.25 & 148.54 \\
\hline $\mathbf{2 .}$ & 5429.76 & 84.19 & 3.85 & 0.01 & 209.37 & 3.49 & 5312.52 & 85.55 \\
\hline $\mathbf{3 .}$ & 5829.24 & 74.58 & 3.91 & 0.01 & 228.32 & 3.09 & 5756.46 & 75.79 \\
\hline $\mathbf{4}$ & 5906.07 & 127.96 & 3.97 & 0.02 & 234.91 & 5.30 & 5886.01 & 130.03 \\
\hline $\mathbf{5 .}$ & 5981.94 & 199.12 & 4.05 & 0.03 & 242.67 & 8.25 & 6032.71 & 202.35 \\
\hline $\mathbf{6 .}$ & 5892.45 & 277.16 & 4.13 & 0.04 & 243.95 & 11.4 & 6016.10 & 281.65 \\
\hline$\geq 7$. & 5604.54 & 380.19 & 4.23 & 0.06 & 238.27 & 15.7 & 5815.64 & 386.35 \\
\hline F-test & \multicolumn{2}{|c|}{$f_{\text {tab }}=19.707^{* *}$} & $f_{\text {tab }}=6.66^{* *}$ & $f_{\text {tab }}=18.299 * *$ & $f_{\text {tab }}=18.960^{* *}$ \\
\hline
\end{tabular}


PM-proizvodnja mleka / MP - Milk production

SMM-sadržaj mlečne masti / CMF - Content of milk fat

PMM-proizvodnja mlečne masti / MFP - Milk fat production

4\%MKM-proizvodnja $4 \%$ mast-korigovanog mleka / 4\% FCM - production of fat corrected milk

Table 2. General average, mean values of least squares and their errors and significance of the effect of season of calving on milk traits

Tabela 2. Opšti prosek, srednje vrednosti najmanjih kvadrata i njihove greške i značajnost uticaja sezone telenja na osobine mlečnosti

\begin{tabular}{|c|c|c|c|c|c|c|c|c|}
\hline $\begin{array}{c}\text { Sezona } \\
\text { Season }\end{array}$ & $\begin{array}{c}\text { PM } \\
\text { MP }\end{array}$ & Slsm & $\begin{array}{c}\text { SMM } \\
\text { CMF }\end{array}$ & Slsm & $\begin{array}{c}\text { PMM } \\
\text { MFP }\end{array}$ & Slsm & $\begin{array}{c}4 \% \text { MKM } \\
4 \% \text { FCM }\end{array}$ & $\begin{array}{c}\text { Slsm } \\
\text { Op. Prosek / Gen. Av. }\end{array}$ \\
\hline \multicolumn{2}{|c|}{$5.630 .27 \mathrm{~kg}$} & \multicolumn{2}{|c|}{$3.98 \%$} & \multicolumn{2}{|c|}{$225.22 \mathrm{~kg}$} & $5.630 .38 \mathrm{~kg}$ \\
\hline I. & 5635.68 & 120.61 & 3.99 & 0.01 & 225.48 & 5.00 & 5636.34 & 122.57 \\
\hline II. & 5678.29 & 120.80 & 3.98 & 0.02 & 226.32 & 5.00 & 5666.11 & 122.76 \\
\hline III. & 5657.86 & 117.97 & 4.00 & 0.02 & 227.27 & 4.89 & 5672.25 & 119.89 \\
\hline IV. & 5549.26 & 118.41 & 3.98 & 0.02 & 221.81 & 4.90 & 5546.83 & 120.33 \\
\hline F-test & \multicolumn{2}{|c|}{$f_{\text {tab }}=1.112^{\boldsymbol{n s}}$} & \multicolumn{2}{|c|}{$f_{\text {tab }}=2.086^{\boldsymbol{n s}}$} & $f_{\text {tab }}=1.193^{\boldsymbol{n s}}$ & $f_{\text {tab }}=1.149^{\boldsymbol{n s}}$ \\
\hline
\end{tabular}

N.S $-\mathrm{P}>0.05 ; *-\mathrm{P}<0.05 ; * *-\mathrm{P}<0.01$

PM-proizvodnja mleka / MP - Milk production

SMM-sadržaj mlečne masti / CMF - Content of milk fat

PMM-proizvodnja mlečne masti / MFP - Milk fat production

4\%MKM-proizvodnja $4 \%$ mast-korigovanog mleka / 4\% FCM - production of fat corrected milk

Data presented in table 1 show that order of lactation influenced highly significant deviations $(\mathrm{P}<0,01)$ of milk yield, content of milk fat, production of milk fat and $4 \% \mathrm{FCM}$ from general average. Production of milk is characterized by regular trend of increase with lactations, therefore production of milk is lowest in the first lactation where deviation from the general average was- $862,38 \mathrm{~kg}$, and the highest in the fifth lactation with deviation from the general average of $351,66 \mathrm{~kg}$. Considerable effect $(\mathrm{P}<0,05)$ of lactation on milk yield is stated by Lazarević et al. (1985), and highly considerable by Trifunović et al. (2002).

Identical situation is with content of milk fat since here we also have trend of increase from the first $3,77 \%$ to the seventh lactation $4,23 \%$.

Order of lactation had highly significantly influenced $(\mathrm{P}<0,01)$ the variations in milk yield. The greatest negative deviation of $-46,16 \mathrm{~kg}$ and the lowest production $179,07 \mathrm{~kg}$ were determined in first lactation. Slowly production increased to $243,95 \mathrm{~kg}$ in sixth lactation where the highest positive deviation was determined - 18,73 kg. Similar conclusions were made by Trifunovic et al. (2002) who determined highly significant effect of order of lactation on yield of milk fat.

In order to compare more efficiently production of milk often $4 \%$ fat corrected milk is used. Order of lactation demonstrated highly significant effect $(\mathrm{P}<0,01)$ on yield of $4 \% \mathrm{FCM}$. The lowest production was achieved in first lactation $4.593,25 \mathrm{~kg}$ with deviation from general average of $-1.037,13 \mathrm{~kg}$. Production gradually increased and in fifth lactation reached its maximum of $6.032,71 \mathrm{~kg}$ with deviation of 402,32 $\mathrm{kg}$.

Considering the fact that bull dams represent the best cows of main herd obtained results are considerably better than results obtained in research carried out on broader population of Simmental breed by Petrović M. (2000), Lazarević et al. (1985). Somewhat higher results are stated by Schweizerischer Fleckviehzuchtverband (1998) - Swiss Association of Breeders of Simmental Cattle also for wider population, and considerably higher results by Pumberger R., Pichler R., (2001) and Schweizerischer Fleckviehzuchtverband (1998) for bull dams of Simmental breed.

Calving season demonstrated no statistically significant effect $(\mathrm{P}>0,05)$ on any of the investigated milk traits (table 2). Production was rather equal and without any considerable oscillations. Petrović $M$. M. Et al. (1997) state highly significant effect of season of calving on production of milk, milk fat and $4 \%$ FCM compared to general average $(\mathrm{P}<0,01)$. 


\title{
Conclusion
}

Milk yield of cows increases approximately until they reach age of five years, or in other words during first three lactations. After 5th year, until cows reach age of approx. 8 to 9 years, increase is slight or it stagnates and afterwards it starts to decrease considerably and in 15th and 16th year it is approximately same as milk yield of first calving cows.

Average production of milk of bull dams in standard lactation was $5.630 .27 \mathrm{~kg}$ with $225,22 \mathrm{~kg}$ of milk fat and $3.98 \%$ milk fat content.

Order of lactation demonstrated highly significant effect $(\mathrm{P}<0,01)$ on all milk traits contrary to calving season without significant effect $(\mathrm{P}>0,05)$ on any of the investigated milk traits.

Knowledge of the power of the paragenetic effects on production traits is very important considering their significance in realization of breeding goal and good economical results.

\section{FENOTIPSKA VARIJABILNOST OSOBINA MLEČNOSTI BIKOVSKIH MAJKI SIMENTALSKE RASE}

\author{
V. Pantelić, Z. Skalicki, M. M. Petrović, S. Aleksić, B. Miščević, Dušica Ostojić
}

$$
\text { Rezime }
$$

Prinos mleka je najznačajnija osobina mlečnosti i utvrđuje se za celu laktaciju, kao i za standardnu u trajanju od 305 dana.Proizvodnja mleka u standardnim laktacijama, odnosno laktacijama od 305 dana, omogućava međusobno poređenje laktacija različite dužine trajanja.

Krave značajnije povećavaju mlečnost do približno 5 . godine života, odnosno tokom prve tri laktacije. Posle 5. godine do približno 8. ili 9. godine povećanje je neznatno ili mlečnost stagnira, a zatim značajnije počinje da opada da bi se u 15. ili 16. godini ponovo smanjila, približno na mlečnost prvotelki.

Prosečna proizvodnja mleka bikovskih majki u standardnoj laktaciji iznosila je $5.630 .27 \mathrm{~kg}$ sa $225,22 \mathrm{~kg}$ mlečne masti i 3.98\% sadržaja masti u mleku .

Laktacija po redu imala je visoko značajan uticaj $(\mathrm{P}<0,01)$ na sve osobine mlečnosti za razliku od sezone telenja koja nije imala značajnijeg uticaja $(\mathrm{P}>0,05)$ ni na jednu od ispitivanih osobina.

Poznavanje jačine spoljašnjih uticaja na proizvodne osobine veoma je važno s obzirom na njihov značaj pri ostvarenju odgajivačkog cilja i postizanja dobrih ekonomskih rezultata.

Ključne reči: bikovske majke, simentalska rasa, osobine mlečnosti, laktacija, sezona telenja,

\section{Literature}

1. HARVEY W.R (1987): Mixed model Least Squares and maximum Likelihood Computer Program. User, s Guiede for LSML MW and MIX MDL.

2. LAZAREVIĆ, R., ROMČEVIĆ, LJ., VASOVIĆ, S., NIKITOVIĆ, N., MIHAJLOV, B. (1985): Varijabilnost proizvodnih i reproduktivnih osobina krava simentalske rase. Savremena poljoprivreda, vol. 33, (1-2) str. 5-16.

3. PETROVIĆ, M. (2000): Ispitivanje dugovečnosti, proizvodnje mleka i mlečne masti krava simentalske rase. Magistarski rad. Poljoprivredni fakultet, Beograd.

4. PETROVIĆ, M.M., LAZAREVIĆ, R., LAZAREVIĆ, LJ., ALEKSIĆ, S.,MiŠČEVIĆ, B., PERKOVIČ, S., (1997): Proizvodni efekti selekcije aktivne populacije simentalskih goveda u Srbiji. Biotehnologija u stočarstvu (3-4) p.57-64.

5. PUMBERGER, R., PICHLER, R., (2001): Fleckviehzucht in Osterreich. Osterreichische bundes fleckviehschau mit fleckvieh elite auktion. Rieder Messe.

6. SCHWEIZER FLECKVIEH (1998): No.7, 3-25: Annual report 1997/98.

7. SMITH, V.R.,(1965): Physiology of lactation. Fifth ed. ISU Press, USA.

8. TRIFUNOVIĆ, G., LATINOVIĆ, D., SKALICKI, Z., ĐEDOVIĆ RADICA, PERIŠIĆ, P., (2002): Uticaj određenih paragenetskih faktora na osobine mlečnosti populacije crno-belih goveda. Biotehnologija $u$ stočarstvu 18 (5-6) p.43-49. 